\title{
ANALISIS KELAYAKAN FUNGSI WISATA SEBAGAI STRATEGI PENGEMBANGAN BUMI PERKEMAHAN SIBOLANGIT
}

\section{FEASIBILITY ANALYSYS OF TOURISM FUNCTION AS SIBOLANGIT CAMPGROUND DEVELOPMENT STRATEGY}

\author{
Yunita Syafitri Rambe \\ Program Studi Arsitektur, Fakultas Teknik, Universitas Medan Area , Indonesia \\ Diterima: Maret 2021; Disetujui: April 2021; Dipublikasi: April 2021 \\ *Corresponding author: yunirambe@staff.uma.ac.id
}

\begin{abstract}
Abstrak
Kawasan Perkemahan Sibolangit merupakan suatu Kawasan Ruang Terbuka sebagai daerah resapan pada Kawasan Kecamatan Sibolangit. Pada saat ini, perkemahan Sibolangit selain dijadikan daerah bagi perkemahan juga dibuka untuk pengunjung dan wisatawan umum. Kawasan perkemahan Sibolangit mempunyai topografi yang berbukit-bukit, terdapat sungai dan pohon-pohon. Pada saat ini, sudah mulai bermunculan beberapa bangunan yang dibangun tidak sesuai dengan kebutuhan lahan. Padahal sebuah Kawasan wisata diperlukan suatu strategi dalam pengembangannya. Usaha pariwisata yang baik adalah usaha pariwisata yang memperhatikan kekhasan, keunikan, keanekaragaman serta kebutuhan manusia untuk berwisata. Dari latar belakang yang ada, maka diperlukannya suatu analisis kelayakan sebagai suatu strategi dalam pengembangan Kawasan perkemahan Sibolangit sebagai suatu Kawasan wisata. Penelitian ini menggunakan metodologi kualitatif dengan metode SWOT untuk mengetahui kendala, ancaman eksternal, prospek yang menghasilkan strategi untuk dijadikan konsep pengembangan yang baik. Luaran dari penelitian ini diharapkan menjadi dasar dalam strategi konsep pengembangan Kawasan Perkemahan Sibolangit dan juga diharapkan dapat berguna bagi penelitian lainnya.
\end{abstract}

\section{Kata Kunci: Kelayakan fungsi, Pariwisata, SWOT, Kawasan Sibolangit}

\begin{abstract}
Sibolangit Camping Area is an Open Space Area as a catchment area in sibolangit sub-district. At this time, Sibolangit camp in addition to being an area for the camp is also open to visitors and general tourists. Sibolangit's campsite has hilly topography, there are rivers and trees. At this time, it has started to appear some buildings that are built not in accordance with the needs of the land. Whereas a tourist area needed a strategy in its development. A good tourism business is a tourism business that pays attention to the peculiarities, uniqueness, diversity and human needs to travel. From the existing background, it is necessary suatu feasibility analysis as a strategy in the development of Sibolangit camp area as a tourist area. This research uses qualitative methodology with SWOT method to know constraints, external threats, prospects that produce strategies to be used as a good development concept. The externality of this research is expected to be the basis in the concept strategy of sibolangit camp area development and is also expected to be useful for other research.
\end{abstract}

\section{Keywords: Feasibility of function, Tourism, SWOT, Sibolangit Area}

How to Cite : Rambe. Yunita Syafitri (2020). Analisis Kelayakan sebagai Strategi Pengembangan Bumi Perkemahan Sibolangit menjadi daerah wisata. JAUR (Journal of Architecture and Urbanism Research). 4 (2): 181-193 


\section{PENDAHULUAN}

Kawasan Sibolangit merupakan suatu Kawasan Ruang Terbuka Hijau yang berfungsi ekologis, sosial budaya, estetika dan ekonomi. Secara Kualitas, perlu adanya pengembangan terhadap kawasan yang memberikan kenaikan nilai kepada lingkungan dan penghuninya. Kawasan ini juga dapat dikategorikan kawasan yang harus diselamatkan untuk menjamin kelestarian fungsi lingkungan yang secara rentan terhadap bencana. (Rambe, 2020)

Kawasan Sibolangit secara topografi terdiri dari bukit-bukit terletak di kaki Gunung Sibayak dengan udara yang sejuk dengan ketinggian 864 meter diatas permukaan laut. Jarak Medan ke Bumi Perkemahan Pramuka Sibolangit $\pm 45 \mathrm{~km}$ (Medan - Brastagi $\pm 60 \mathrm{KM}$ ). Dalam areal Bumi Perkemahan terdapat banyak sungai kecil yang airnya jernih dan curah hujan cukup tinggi. Pada musim Liburan sekolah para Pramuka yang $99 \%$ adalah pelajar sering mengadakan perkemahan di tempat ini, mendapatkan rekreasi yang sehat dialam terbuka dengan biaya relatip murah setelah banyak waktu yang terpakai di kota. Pada saat ini, banyak penggarap liar yang menggarap tanah di dalam Bumi Perkemahan Pramuka Sibolangit karena tidak jelasnya batas-batas lahan kurang tertibnya pengelolaan Bumi Perkemahan.

Selain digunakan sebagai bumi perkemahan (Camping Ground) untuk kegiatan kepanduan, Bumi Perkemahan Pruka Sibolangit mempunyai potensi yang sangat besar untuk dikembangkan menjadi tempat wisata misalnya Kegiatan Out Bound. Bentuk lahan yang berkontur serta beradi dataran tinggi, memberikan kelebihan tersendiri bagi tempat ini yaitu udara yang sejuk dan pemandangan yang indah. Adanya hutan wisata dan air terjun Dwi Warna yang tidak jauh letaknya dari bumi perkemahan, sangat mendukung untuk pengembangan Bumi Perkemahan Pramuka Sibolangit sebagai tempat wisata keluarga.

Adapun Kebijakan RTRW Kabupaten

Deli Serdang dengan tujuan penataan ruang wilayah Kabupaten Deli Serdang pada dasarnya ditujukan untuk menggambarkan Rencana Tata Ruang Wilayah Kabupaten Deli Serdang yang ingin dicapai serta mampu menjawab permasalahan tata ruang saat, antara lain (a) Peningkatan pusat-pusat pelayanan wilayah dan pusat-pusat kegiatan ekonomi secara merata sesuai dengan daya dukung dan potensinya; (b) Meningkatkan aksesibilitas dan kualitas pelayanan transportasi ke seluruh wilayah dan wilayah di sekitar Kabupaten Deli Serdang. (c) Meningkatkan kualitas dan jangkauan pelayanan jaringan telekomunikasi, sumber daya energi, dan sumber daya air yang terpadu dan merata di seluruh wilayah kabupaten.(Serdang, 2019)

Dari hasil identifikasi, permasalahan pokok yang terkait dengan pengembangan potensi obyek wisata di Kecamatan Sibolangit adalah jumlah kunjungan wisatawan yang masih rendah, padahal diharapkan dengan kunjungan yang banyak dapat meningkatkan kontribusi pariwisata terhadap pendapatan masyarakat dan pemerintah daerah. Banyaknya jumlah obyek wisata yang belum mendapat perhatian dan pengelolaan secara baik, serta pengelolaan dan pengembangan obyek wisata yang belum memperhatikan potensi dan strategi pengembangan. Usaha pariwisata yang baik adalah usaha pariwisata yang memperhatikan kekhasan, keunikan, keanekaragaman serta kebutuhan manusia untuk berwisata. Hal ini menjadi kendala dalam pengembangan wisata yang ada di Kecamatan Sibolangit

Selain itu terdapat wacana oleh pemerintah daerah untuk mengembalikan fungsi Kawasan Sibolangit menjadi Kawasan Bumi Perkemahan. Hal ini juga 
dilatarbelakangi oleh lokasi tersebut telah banyak disalahgunakan, lantaran dikuasai oleh pihak-pihak yang tidak berhak.(Https://diskominfo.sumutprov.go.i d/, 2020)

Untuk mengetahui pengembangan suatu Kawasan diperlukan suatu studi analisis kelayakan. Pengertian studi kelayakan menurut Andri Kristanto adalah merupakan tahap yang paling penting, karena di dalamnya menyangkut berbagai aspek sistem yang baru yang diusulkan. Sedangkan menurut O'Brien adalah studi awal untuk merumuskan informasi yang dibutuhkan oleh pemakai akhir, kebutuhan sumber daya, biaya, manfaat dan kelayakan proyek yang diusulkan. Pengertian layak disini adalah kemungkinan dari gagasan usaha atau proyek yang akan dilaksanakan memberikan manfaat benefit baik dalam arti financial benefit maupun dalam arti social benefit. Layaknya suatu gagasan usaha atau proyek dalam arti social benefit tidak selalu menggambarkan layak dalam arti financial benefit, hal ini tergantung dari segi penilaian yang dilakukan. Jadi, menurut beberapa definisi diatas dapat disimpulkan bahwa studi kelayakan yaitu bertujuan untuk mengkaji apakah suatu proyek tersebut layak dikembangkan atau tidak. (Ramdan \& Ihkwana, 2016)

Tolak Ukur dari Analisa Kelayakan ini dengan melihat (a) daya dukung Fisik dan Lingkungan (b) Prospek Pertumbuhan Ekonomi Masyarakat (c) Daya Dukung Prasarana dan Fasilitas Lingkungan (d) Kajian Aspek Signifikansi Historis Kawasan. (Kementerian Pekerjaan Umum dan Perumahan Rakyat \& Konstruksi, 2017)

Tujuan dari penelitian ini adalah untuk menganalisis kelayakan dalam pengembangan suatu Kawasan dinilai dari aspek kendala dan prospek yang menjadi dasar adanya strategi pengembangan.

\section{METODOLOGI PENELITIAN}

Penelitian ini dilaksanakan di Kawasan Perkemahan Sibolangit. Dalam penelitian ini, metode penelitian yang digunakan adalah penelitian Kualitatif. Metode penelitian kualitatif digunakan untuk mendapatkan data yang mendalam, suatu data yang mengandung makna. Pendekatan kualitatif yang bersifat deskriptif ini bertujuan untuk membuat deskripsi, gambaran secara sistematis, faktual dan akurat mengenai fakta-fakta, sifat-sifat serta hubungan antar fenomena yang diselidiki .(Sugiyono, 2017)

Pada penelitian, data-data yang diambil berdasarkan data informasi dari dinas setempat dalam pengembangan kawasan area Sibolangit. Data juga berasal dari data-data survey yang dilakukan pada lokasi penelitian. Data-data yang ada diolah dengan metode SWOT untuk mendapatkan hasil penilaian terhadap kelayakan fungsi pariwisata pada lokasi penelitian.

Analisis data yang digunakan adalah analisis kualitatif deskriptif dan analisis SWOT untuk mengetahui kendala dan prospek serta mengetahui strategi sebagai kelayakan dan kelanjutan dalam pengembangan Kawasan Sibolangit. Matriks SWOT dapat menggambarkan secara jelas bagaimana peluang dan ancaman eksternal yang dapat disesuaikan dengan kekuatan dan kelemahan yang dimiliki. (Rangkuti, 2017)

Analisis komperhensif SWOT (Strength, Weakness, Opportunity and Threat) umumnya digunakan untuk melihat variabel internal dan variabel eksternal yang mempengaruhi sistem. Kekuatan dan Kelemahan digunakan untuk melihat kemampuan dan kekurangan variabel internal yang berpengaruh terhadap kinerja sistem. Kondisi eksternal diluar sistem yang 
mempunyai pengaruh positif atau negatif terhadap sistem dianalisis menggunakan Peluang dan Tantangan.(Rangkuti, 2017)

\begin{tabular}{lll}
\hline $\begin{array}{l}\text { Internal } \\
\text { Eksternal }\end{array}$ & $\begin{array}{l}\text { KEKUATAN } \\
\text { (Strength) }\end{array}$ & $\begin{array}{l}\text { KELEMAHAN } \\
\text { (Weakness) }\end{array}$ \\
\hline $\begin{array}{l}\text { PELUANG } \\
\text { (Opportunity) }\end{array}$ & SO & WO \\
$\begin{array}{l}\text { ANCAMAN } \\
\text { (Threat) }\end{array}$ & ST & WT \\
\hline
\end{tabular}

Kekuatan adalah unsur potensi sumberdaya yang dapat melindungi dari persaingan dan dapat menciptakan suatu kemajuan di dalam suatu kegiatan atau usaha.

Kelemahan adalah unsur potensi sumberdaya yang tidak dapat bersaing sehingga tidak dapat menciptakan suatu kemajuan di dalam kegiatan atau usaha.

Peluang adalah unsur lingkungan yang dapat memungkinkan suatu kegiatan atau usaha mendapatkan keberhasilan yang tinggi.

Ancaman adalah unsur lingkungan yang dapat mengganggu atau menghalangi suatu kegiatan atau usaha jika tidak ada tindakan pengelolaan yang tegas diambil.

Menurut Laoh (1990) analisis SWOT ada tiga strategi yang dapat diterapkan yaitu:

Strategi Agresif, bila hasil interaksi antara kekuatan dan kelemahan dengan peluang dan ancaman dimana jumlah kekuatan lebih besar dari jumlah kelemahannya.

Strategi Bertahan, bila hasil interaksi antara kekuatan kelemahan dengan peluang dan ancaman dimana jumlah kekuatan sama dengan jumlah kelemahannya.

Strategi Persiapan, bila hasil interaksi antara kekuatan dan kelemahan dengan peluang dan ancaman dimana jumlah kekuatan lebih kecil dari jumlah kelemahannya.(Rangkuti, 2017)

Dalam menggambarkan hasil analisis SWOT digunakan matrik SWOT seperti pada tabel dibawah ini.

\begin{tabular}{llll}
\hline $\begin{array}{l}\text { Q } \\
\begin{array}{l}\text { Mendukung } \\
\text { Penciutan }\end{array}\end{array}$ & Strategi & $\begin{array}{l}\text { Mendukung } \\
\text { Agresif }\end{array}$ & Strategi \\
\hline & & P & \\
$\begin{array}{l}\text { Mendukung } \\
\text { Bertahan }\end{array}$ & Strategi & $\begin{array}{l}\text { Mendukung } \\
\text { Diversifikasi }\end{array}$ & Strategi \\
\hline
\end{tabular}

Secara skematik, metodologi penelitian dapat dilihat pada diagram berikut ini :

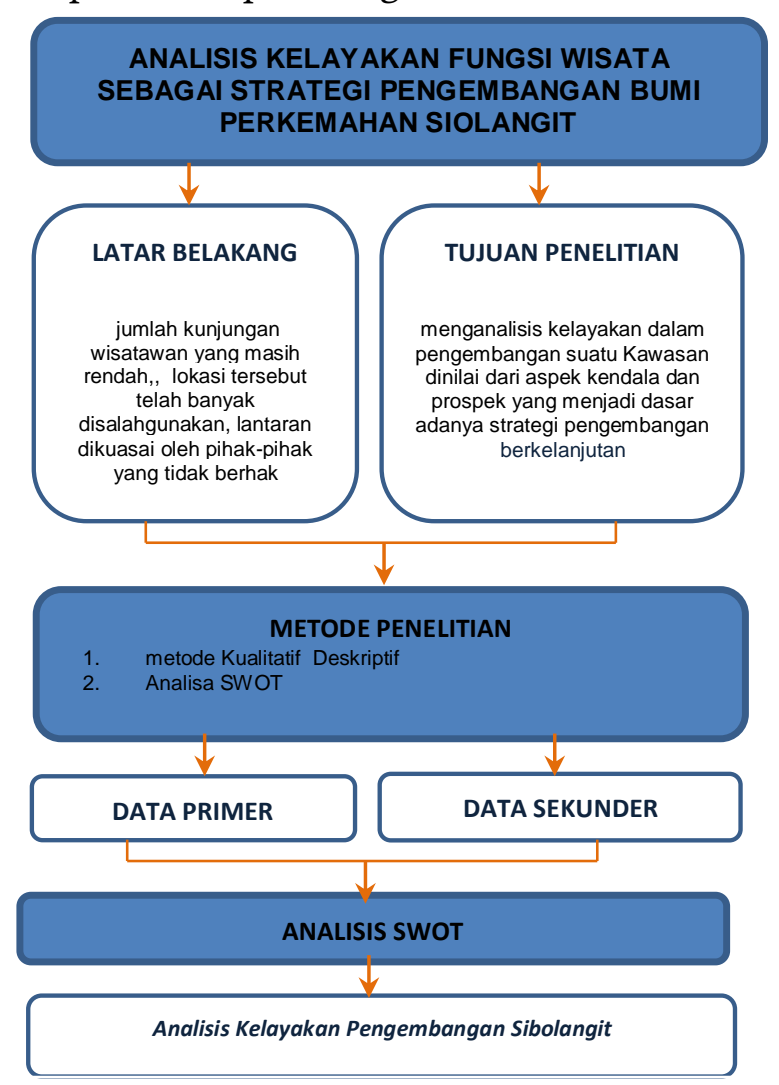

Gambar 1. Diagram Penelitian Sumber : Pengolahan Data

\section{PEMBAHASAN}

Pada Kawasan Sibolangit, terdapat beberapa sarana prasarana yang dijadikan wisata bagi masyarakat luas. Adapun beberapa dianataranya yaitu:

Perkemahan : Tapak Kemah dengan luas 80 ha yang terbagi menjadi 2 kelurahan yaitu : Kelurahan Putra dan Putri masingmasing seluas 40 ha dan di bagi menjadi masing-masing 5 kelurahan (Kelurahan Putra : I, II, II, IV, V dan Kelurahan Putri : I, II, III, IV, V), dan dilengkapi sarana 
pendukung , Pendopo, Pondok Pembina, lapangan upacara dan 7 unit MCK dengan kapasitas per unit 12 kamar mandi (shower) dan 12 kloset, air yang cukup, alat penerangan, tenda-tenda (kemah dan terbuka ), jalan beraspal, berliku-liku, naik turun tepat untuk kegiatan, gerak jalan, jogging, bersepeda. Seluruh tapak kemah dapat menampung lebih dari 20.000 orang.

Lapangan Utama terdapat lapangan Utama dengan luas 5 ha dilengkapi dengan tribun terbuka yang dapat menampung 20.000 orang, hijau dan asri, bisa dipakai untuk kegiatan ; Upacara, Famili Gathering, Ulang tahun Perusahaan, Bazaar, Konser music, Olah Raga ( senam, aerobik, sepak bola dll ).

Lapangan Sultan, Lahan seluas 2 ha untuk kegiatan sepak bola dilengkapi dengan 1 unit ruang ganti pakaian dan MCK.

Penginapan, tersedia akomodasi kamar/wisma baik yang AC/non AC yang berada di Graha Wisata maupun dekat dengan perkemahan dengan kapasitas yang berbeda dan dapat menampung 486 orang, seperti; kamar Youth Hostel Graha Wisata, Kencono Wungu, serta wisma-wisma Pertiwi, Imam Bonjol, Patimura, Untung Surapati, Hos Cokro Aminoto, Teuku Cik Ditiro, Teuku Umar, Pangeran Jayakarta dan Satria dengan harga terjangkau.

Aula/Loka , merupakan sarana yang dapat digunakan sebagai tempat kegiatan pendidikan, seminar, rapat, pertemuan, pesta pernikahan, wisuda dll, Aula /loka /ruangan - ruangan yang AC dan non AC dengan kapasitas $60 \mathrm{~s} / \mathrm{d} 800$ orang, seperti : Cut Nyak Dien, Cut Mutia, Srikandi, Dewi Shinta, Dasa Dharma, Cemara, Mahoni, Dewi Sartika, MH.Thamrin dan I Gusti Ngurah Rai.

Catering dan Cafetaria Pamitran Buperta, menyediakan berbagai macam menu Makan baik untuk kegitan di Buperta maupun diluar Buperta, ada Nasi bungkus, Nasi Box, Prasmanan, tumpeng, kambing guling, sate serta berbagai macam menu snack, ada Box, Prasmanan, rebusan, teh /kopi manis dan susu dengan harga bervariasi dapat melayani sampai dengan 5000 orang, dilengkapi juga Ruang Makan Kendedes dengan kapasitas 120 kursi. Cafetaria Pamitran melayani konsumsi langsung.

Toko Jambore, menjual perlengkapan Pramuka dan berbagai souvenir.

Danau Situ Baru, seluas 8 ha dikelilingi areal terbuka hijau dapat digunakan berbagai macam kegiatan Rekreasi wisata Air dengan sepeda Air, perahu naga, speedboat, banana boat, kano, water ball, Olah raga Air, Latihan SAR, Out Bound, Shooting Film dan wahana bermain lainnya.

Sarana Out Bound dan Paint Ball, dengan berbagai macam model dan game yang ada baik untuk permainan high maupun low dan dilengkapi menara panjat tebing, mountenering yang kini sangat digemari para remaja. Sarana Paint Ball juga permainan yang sangat menantang, permainan perang-perangan dengan memakai peluru berisi cat dan perlengkapan perang yang layaknya ketika kita akan memasuki sebuah medan pertempuran.

Kolam Renang, merupakan sarana rekreasi keluarga dan olah raga yang dilengkapi 2 kolam renang Anak dan 1 kolam renang Dewasa serta Panggung terbuka untuk hiburan, bisa dipergunakan untuk acara Silaturrahmi, Arisan Keluarga, Perpisahan Sekolah dan lain-lain.

Sarana Pendukung, untuk pelayanan tamu yang berkegiatan di Buperta tersedia beberapa lapangan parkir yang cukup luas dapat menampung \pm 1000 unit kendaraan, listrik PLN, Air bersih yang cukup, dan 
masih banyak fasilitas yang lain seperti, kursi meja sofa, velbed, kayu bakar untuk api unggun, tiang bendera, kursi lipat, meja lapangan, wirelles, Sound System dll.

Sarana Peribadatan, Untuk memudahkan pengunjung yang berkegiatan/ kemah di Buperta khususnya dalam melaksanakan Ibadah, di areal Bumi Perkemahan tersedia 5 gedung peribadatan seperti ; Masjid, Gereja, Kapel, Wihara dan Pura.

Gedung sanggar Saka, di Buperta terdapat sanggar-sanggar satuan karya pramuka seperti ; Taman lalu Lintas, Dirgantara, Bahari, Wanabhakti, Taruna Bumi, Bakti Husada, Kencana dan Wirakartika.

\section{Analisa Peruntukan Lahan}

Secara umum peruntukan lahan Bumi Perkemahan Sibolangit terbagi menjadi beberapa elemen antara lain pada bagian barat terdapat perkemahan-perkemahan dan bangunan PTPN, dan lahan kosong yang ditanami pohon pinus. Kegiatan perkemahan pun lebih sering dilakukan pada bagian barat bumi Perkemahan Sibolangit. Pada bagian timur Bumi Perkemahan Sibolangit terdapat fasilitas pendidikan, fasilitas peribadatan, pemukiman, fasilitas pemerintahan dan ladang. Pada bagian timur ini lah terdapat Kantor Camat. Untuk daerah yang berada di dalam lingkup jalan utama sebagian besar didominasi oleh fasilitas Pemerintahan dan Perdagangan yang berupa rumah makan. Kemudian terdapat pula ruang-ruang terbuka di antara kumpulan perkemahanperkemahan, bangunan PTPN, dan pemukiman, namun kondisinya tidak begitu baik dan tidak dimanfaatkan. Dengan melihat hal-hal diatas dapat disimpulkan Bumi Perkemahan Sibolangit telah memiliki teritori tata guna lahan bagi masing-masing elemen namun teritori tersebut masih belum jelas. Jika teritori peruntukan lahan tersebut dapat diperjelas tentu saja citra daerah Bumi Perkemahan Sibolangit akan menjadi baik, sebaliknya apabila kondisinya tetap dibiarkan seperti itu akan berakibat buruk bagi Bumi Perkemahan Sibolangit.

\section{Analisa SWOT}

Berdasarkan hasil penelitian yang dilakukan dan perolehan data yang ada, maka informasi yang didapat akan dipetakan dengan menggunakan Analisa SWOT. Dalam Analisa kelayakan ini, akan diidentifikasikan kekuatan, kelemahan, peluang dan ancaman serta strategi yang akan dilakukan. Proses identifikasi ini akan dilanjutkan dalam bentuk persilangan/ matriks untuk menentukan strategi kelayakan dalam pengembangan Kawasan.(Andajani et al., 2017)

\section{SWOT Daya Dukung Fisik Dan Lingkungan}

Daya dukung lingkungan merupakan jumlah maksimum manusia yang dapat didukung oleh bumi dengan sumber daya alam yang tersedia. Pada proses analisa kelayakan yang dilakukan, diperlukannya analisis daya dukung Fisik dan Lingkungan. Hal ini dilakukan karena dalam setiap lingkungan, nilai positif dan negatif suatu kawasan dapat menjadi faktor penting dalam pengembangannya. Pada hakekatnya setiap area wisata mempunyai kemampuan yang berbeda dalam menyerap jumlah kunjungan, bahkan jika terjadi kelebihan dan tidak mempunyai strategi dalam pengembangan, hal ini akan merusak lingkungan tersebut. (Sukmana \& Suryawan, 2016) 
Tabel 1. Analisa SWOT dan persilangan matriks Daya Dukung Fisik dan Lingkungan

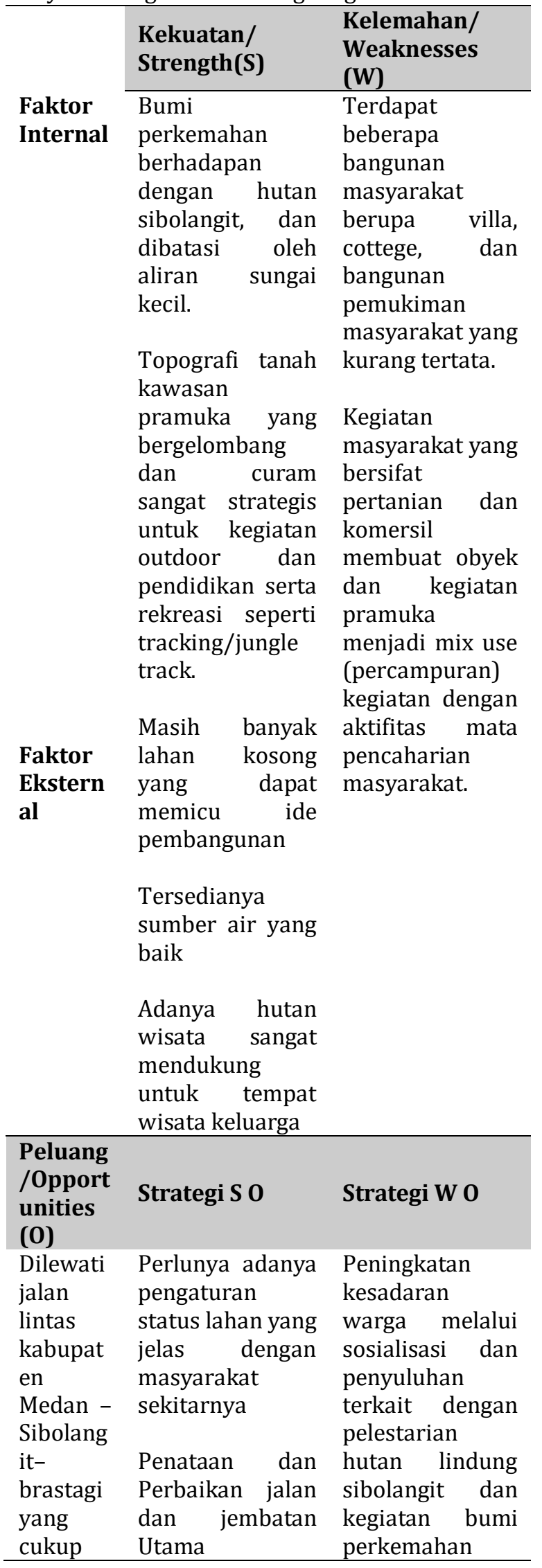

\begin{tabular}{|c|c|c|}
\hline $\begin{array}{l}\text { signifika } \\
\mathrm{n} \text { dalam } \\
\text { pengem } \\
\text { bangan } \\
\text { bumi } \\
\text { perkema } \\
\text { han } \\
\text { sibolang } \\
\text { it yang } \\
\text { lebih } \\
\text { baik }\end{array}$ & $\begin{array}{l}\text { Membuat } \\
\text { peraturan- } \\
\text { peraturan yang } \\
\text { memperjelas } \\
\text { legalisasi } \\
\text { pembentukan } \\
\text { lahan. }\end{array}$ & $\begin{array}{l}\text { pramuka } \\
\text { Perlu adanya } \\
\text { aturan tata letak } \\
\text { bangunan }\end{array}$ \\
\hline $\begin{array}{l}\text { Ancama } \\
\text { n/Thre } \\
\text { ats }\end{array}$ & Strategi S T & Strategi W T \\
\hline $\begin{array}{l}\text { Guna } \\
\text { Lahan } \\
\text { eksisting } \\
\text { banyak } \\
\text { beralih } \\
\text { fungsi } \\
\text { untuk } \\
\text { kepentin } \\
\text { gan } \\
\text { individu } \\
\text { (pribadi } \\
\text { ) } \\
\text { masyara } \\
\text { kat } \\
\text { dalam } \\
\text { menggar } \\
\text { ap } \\
\text { kawasan } \\
\text { bumi } \\
\text { perkema } \\
\text { han } \\
\text { pramuka } \\
\text { sibolang } \\
\text { it }\end{array}$ & $\begin{array}{l}\text { Legalisasi } \\
\text { peruntukan } \\
\text { bangunan di } \\
\text { kawasan bumi } \\
\text { pramuka } \\
\text { sibolangit } \\
\text { Peningkatan dan } \\
\text { partisipasi } \\
\text { kesadaran warga } \\
\text { untuk } \\
\text { kemudahan } \\
\text { pengembangan }\end{array}$ & $\begin{array}{l}\text { Penataan untuk } \\
\text { fungsi kegiatan } \\
\text { pramuka dan } \\
\text { area komersil } \\
\text { (kampong } \\
\text { wisata) terkait } \\
\text { pengembangan } \\
\text { industry } \\
\text { pariwisata } \\
\text { keluarga. }\end{array}$ \\
\hline
\end{tabular}

\section{SWOT Prospek Pertumbuhan Ekonomi Masyarakat}

Pertumbuhan ekonomi masyarakat akan meningkat ataupun menurun pada suatu kawasan wisata disebabkan tidak baiknya perencanaan yang dilakukan. Sehingga pada umumnya upaya pengembangan kawasan wisata berkaitan erat dengan peningkatan poduktifitas sumber daya alam dan juga penanganan sarana dan prasarana sekitar.(Tarigan et al., 2018) Sehingga dengan menganalisis kawasan terhadap sarana dan prsarana serta pertumbuhan ekonomi masyarakat 
setempat, dapat memberikan strategi pengembangan yang baik terhadap suatu kawasan.

Tabel 2. Analisa SWOT dan persilangan matriks Prospek Pertumbuhan Ekonomi Masyarakat

\begin{tabular}{|c|c|c|}
\hline & $\begin{array}{l}\text { Kekuatan } \\
\text { Strength(S) }\end{array}$ & $\begin{array}{l}\text { Kelemahan/ } \\
\text { Weaknesses (W) }\end{array}$ \\
\hline \multirow[t]{2}{*}{$\begin{array}{l}\text { Faktor } \\
\text { Internal }\end{array}$} & $\begin{array}{l}\text { Tersedianya } \\
\text { berbagai } \\
\text { fasilitas pada } \\
\text { kawasan baik } \\
\text { fasilitas jasa, } \\
\text { perdagangan, } \\
\text { peribadatan, } \\
\text { maupun } \\
\text { transportasi }\end{array}$ & $\begin{array}{l}\text { Sumber daya } \\
\text { manusia banyak } \\
\text { yang bekerja di } \\
\text { bidang } \\
\text { pertanian,/ladang } \\
\text { Pertumbuhan } \\
\text { ekonomi yang } \\
\text { belum merata }\end{array}$ \\
\hline & $\begin{array}{l}\text { Pertumbuhan } \\
\text { di kawasan } \\
\text { pemukiman } \\
\text { berkembang } \\
\text { cukup pesat } \\
\text { Pertumbuhan } \\
\text { ekonomi di } \\
\text { sekitar jalan } \\
\text { utama cukup } \\
\text { tinggi sehingga } \\
\text { daerah } \\
\text { tersebut } \\
\text { cenderung } \\
\text { menjadi daerah } \\
\text { komersil } \\
\text { (kampong } \\
\text { wisata). }\end{array}$ & $\begin{array}{l}\text { Daya dukung } \\
\text { infrastruktur } \\
\text { belum optimal } \\
\text { Belum optimalnya } \\
\text { sosialisasi } \\
\text { pengembangan } \\
\text { kawasan pramuka } \\
\text { untuk } \\
\text { meningkatkan } \\
\text { taraf ekonomi } \\
\text { masyarakat } \\
\text { melalui kampong } \\
\text { wisata (area } \\
\text { komersil) }\end{array}$ \\
\hline \multirow[t]{2}{*}{$\begin{array}{l}\text { Faktor } \\
\text { Eksternal }\end{array}$} & $\begin{array}{l}\text { Kawasan } \\
\text { Pramuka } \\
\text { Sibolangit } \\
\text { pasar buah } \\
\text { yang menjadi } \\
\text { sentra } \\
\text { perdagangan } \\
\text { dengan } \\
\text { perputaran } \\
\text { uang yang } \\
\text { cukup tinggi }\end{array}$ & \\
\hline & $\begin{array}{l}\text { Banyaknya } \\
\text { signage sebagai } \\
\text { indikasi } \\
\text { pertumbuhan } \\
\text { ekonomi } \\
\text { masyarakat } \\
\text { sekitarnya. }\end{array}$ & \\
\hline $\begin{array}{l}\text { Peluang/ } \\
\text { Opportun }\end{array}$ & Strategi S 0 & Strategi W 0 \\
\hline
\end{tabular}

\begin{tabular}{|c|c|c|}
\hline & & \\
\hline $\begin{array}{l}\text { Sentra } \\
\text { jalan } \\
\text { lintas } \\
\text { kabupaten } \\
\text { antara } \\
\text { deli } \\
\text { serdang } \\
\text { dan karo } \\
\text { menjadika } \\
\text { n } \\
\text { pengemba } \\
\text { ngan } \\
\text { ekonomi } \\
\text { pariwisata }\end{array}$ & $\begin{array}{l}\text { Mendorong } \\
\text { pertumbuhan } \\
\text { pengembangan } \\
\text { ekonomi } \\
\text { dengan } \\
\text { penyediaan } \\
\text { serta } \\
\text { pembangunan } \\
\text { fisik } \\
\text { Penataan } \\
\text { kawasan yang } \\
\text { dilewati jalan } \\
\text { utama kawasan } \\
\text { pramuka } \\
\text { sibolangit } \\
\text { Upgrading } \\
\text { fasilitas pasar } \\
\text { buah agar } \\
\text { dapat menarik } \\
\text { pertumbuhan } \\
\text { ekonomi } \\
\text { masyarakat. }\end{array}$ & 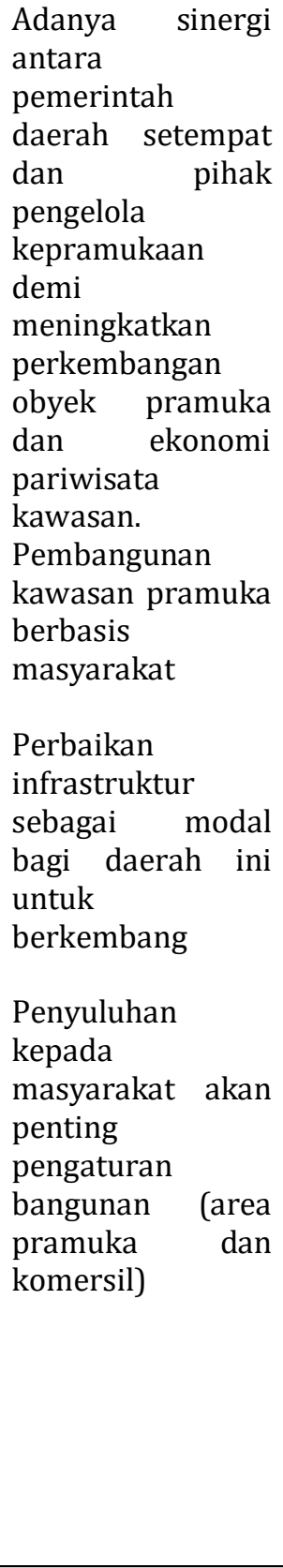 \\
\hline $\begin{array}{l}\text { Ancaman } \\
\text { / Threats }\end{array}$ & Strategi $\mathbf{S ~ T}$ & Strategi W T \\
\hline $\begin{array}{l}\text { Belum } \\
\text { adanya } \\
\text { kesepakan } \\
\text { mengenai } \\
\text { status } \\
\text { lahan } \\
\text { dengan } \\
\text { masyarak } \\
\text { at sekitar } \\
\text { area } \\
\text { pramuka }\end{array}$ & $\begin{array}{l}\text { Mendorong } \\
\text { pertumbuhan } \\
\text { fasilitas } \\
\text { pendukung } \\
\text { yang baik } \\
\text { untuk } \\
\text { mengakomodir } \\
\text { pertumbuhan } \\
\text { ekonomi } \\
\text { kawasan } \\
\text { pramuka } \\
\text { sibolangit (area } \\
\text { komersil) }\end{array}$ & $\begin{array}{l}\text { Identifikasi } \\
\text { ketersediaan } \\
\text { fasilitas yang } \\
\text { belum tersedia } \\
\text { seperti bangunan } \\
\text { sanggar, aula, } \\
\text { mesjid, saung, } \\
\text { diklat, mck, area } \\
\text { outbond, area } \\
\text { kampong wisata, } \\
\text { dll. }\end{array}$ \\
\hline
\end{tabular}




\begin{tabular}{ll}
\hline penggarap & Memaksimalka \\
liar yang & n potensi yang \\
berdomisi & telah dimiliki \\
li di area & kawasan \\
pramuka & pramuka \\
sibolangit & seperti area \\
& kepramukaan \\
& dan pariwisata \\
\hline
\end{tabular}

\section{SWOT Daya Dukung Prasarana Dan}

\section{Fasilitas Lingkungan}

Penilaian analisis Kelayakan daya dukung prasarana dilihat dari beberapa aspek sarana dan prasarana yang tersedia di sekitar Kawasan. Baik dari pencapaian menuju Kawasan maupun sarana yang telah terbangun pada daerah. Hal ini sangat berpengaruh dalam jumlah wisatawan nantinya. Sehingga hal ini menjadi penting dalam Analisa kelayakan, untuk dapat menentukan strategi yang baik terhadap pengembangan suatu Kawasan bumi perkemahan Sibolangit.

Tabel 3. Analisa SWOT dan persilangan matriks Prasarana dan Fasilitas Lingkungan

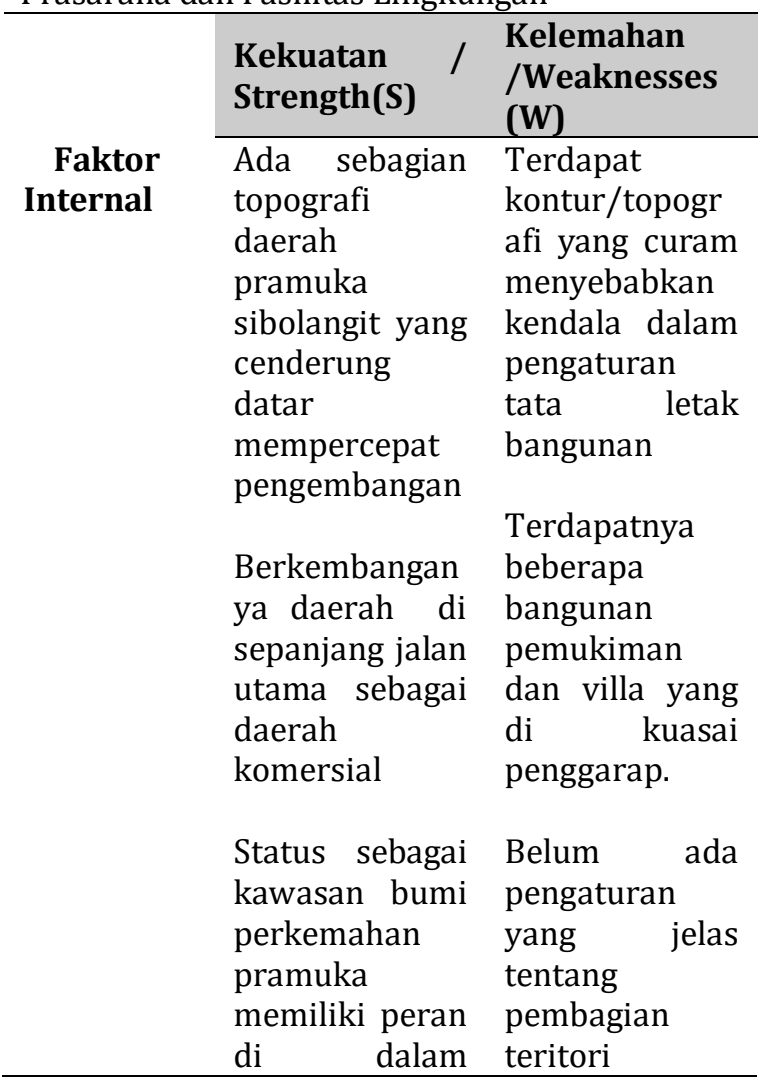

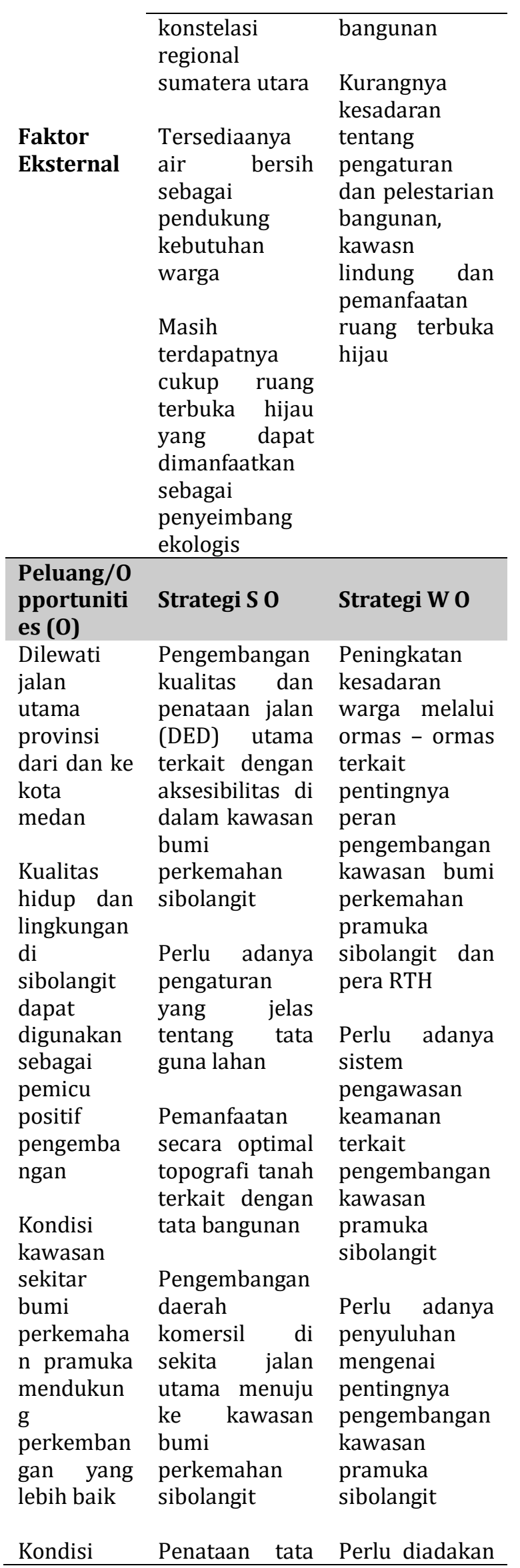




\begin{tabular}{|c|c|c|}
\hline kawasan & bangunan yang & pengaturan \\
\hline pramuka & di sesuaikan & tata letak \\
\hline sibolangit & kaidah & bangunan \\
\hline yang masih & penataan ruang & \\
\hline asri dan & dan lingkungan & Perlu adanya \\
\hline mendukun & untuk menjaga & sosialisasi \\
\hline & keasrian & mengenai \\
\hline pengemba & kawasan bumi & pentingnya \\
\hline ngan sector & perkemahan & pengembangan \\
\hline pariwisata & sibolangit & kawasan \\
\hline $\begin{array}{l}\text { Cout bond } \\
\text { dan wisata }\end{array}$ & & pramuka \\
\hline keluarga) & & \\
\hline baik & & Perlu \\
\hline regional & & penyuluhan \\
\hline dan & & tentang \\
\hline internasion & & kelestarian \\
\hline & & hutan \\
\hline & & (kawasan \\
\hline Menambah & & lindung) \\
\hline pendapata & & terkait dengan \\
\hline n daerah & & penggarap \\
\hline dan & & \\
\hline lapangan & & \\
\hline pekerjaan & & \\
\hline bagi & & \\
\hline masyaraka & & \\
\hline t sekitar. & & \\
\hline $\begin{array}{l}\text { Ancaman/ } \\
\text { Threats }\end{array}$ & Strategi S T & Strategi W T \\
\hline Banyak & Legalitas & \\
\hline status alih & peruntukaan & Penataan \\
\hline fungsi & lahan dan tata & untuk fungsi - \\
\hline lahan yang & bangunan di & fungsi elemen \\
\hline terjadi di & dalam kawasan & kawasan (daya \\
\hline kawasan & bumi & dukung lahan \\
\hline bumi & perkemahan & dan kesesuaian \\
\hline perkemaha & pramuka & lahan serta \\
\hline $\begin{array}{l}\mathrm{n} \\
\text { sibolangit }\end{array}$ & sibolangit. & $\begin{array}{l}\text { bangunan } \\
\text { eksisting yang }\end{array}$ \\
\hline & Peningkatan & telah ada di \\
\hline Orientasi & kesadaran & kawasan bumi \\
\hline wilayah & warga & perkemahan \\
\hline dan batas & (penggarap) & sibolangit. \\
\hline wilayah & tentang & \\
\hline yang masih & pengembangan & \\
\hline menjadi & kawasan bumi & \\
\hline pertentang & perkemahan & \\
\hline an dengan & pramuka & \\
\hline masyaraka & sibolangit & \\
\hline t & terkait dengan & \\
\hline (penggarap & perbaikan & \\
\hline & Peningkatan & \\
\hline & sarana dan & \\
\hline & prasarana & \\
\hline & pendukung & \\
\hline & perkemahan & \\
\hline
\end{tabular}

pramuka

sibolangit

\section{SWOT Kajian Aspek Signifikansi Historis} Kawasan

Dalam suatu teori Goodchild bahwasannya pada suatu daerah objek peninggalan sejarah dan lanskap sejarah terutama yang bernilai signifikan, harus dikonservasi karena merupakan fakta fisik dari warisan sejarah dan budaya yang berkontribusi untuk kepentingan ekonomi masyarakat. (Sukmaratri, 2018) Sehingga analisis kelayakan signifikasi historis ini dilihat dari beberapa variabel seperti keaslian lanskap sejarah, daya tarik wisata sejarah dan kemudahana aksesibilitas.

Tabel 4. Analisa SWOT dan persilangan matriks aspek signifikansi historis kawasan

\begin{tabular}{|c|c|c|}
\hline & $\begin{array}{l}\text { Kekuatan } \\
\text { Strength(S) }\end{array}$ & $\begin{array}{l}\text { Kelemahan } \\
\text { /Weaknesse } \\
\text { s (W) }\end{array}$ \\
\hline $\begin{array}{l}\text { Faktor } \\
\text { Internal }\end{array}$ & 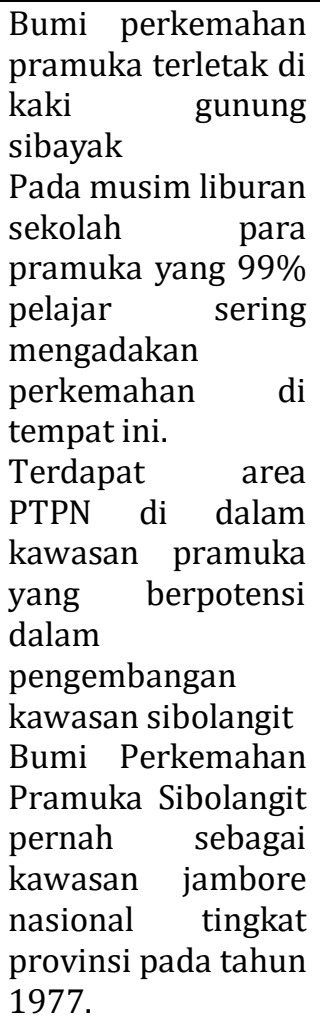 & $\begin{array}{l}\text { Potensi } \\
\text { hilangnya } \\
\text { situs dan } \\
\text { kegiatan } \\
\text { kepramukaan } \\
\text { yang selama } \\
\text { ini menjadi } \\
\text { identitas } \\
\text { kawasan } \\
\text { pramuka } \\
\text { sibolangit }\end{array}$ \\
\hline $\begin{array}{l}\text { Faktor } \\
\text { Eksternal }\end{array}$ & $\begin{array}{lr}\text { Jalan } & \text { utama } \\
\text { kawasan } & \text { pramuka } \\
\text { merupakan } & \text { jalur }\end{array}$ & \\
\hline
\end{tabular}


penghubung antar

$\pm 45 \mathrm{Km}$ Medan -

Brastagi $\pm 60 \mathrm{Km}$

\begin{tabular}{|c|c|c|}
\hline $\begin{array}{l}\text { Peluang/ } \\
\text { Opportuni } \\
\text { ties }(0)\end{array}$ & Strategi S 0 & Strategi W 0 \\
\hline $\begin{array}{l}\text { Kawasan } \\
\text { Pramuka } \\
\text { berpeluan } \\
\text { g untuk } \\
\text { memperka } \\
\text { ya aspek } \\
\text { history } \\
\text { kepramuk } \\
\text { aan } \\
\text { kab.deli } \\
\text { serdang } \\
\text { dan } \\
\text { sumatera } \\
\text { utara }\end{array}$ & 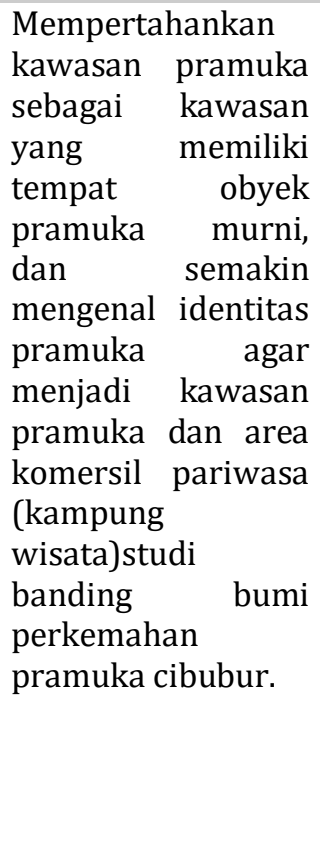 & $\begin{array}{l}\text { Perlu adanya } \\
\text { kajian } \\
\text { mengenai } \\
\text { history lahan } \\
\text { bumi } \\
\text { pramuka } \\
\text { yang lebih } \\
\text { jelas } \\
\text { (legalitas } \\
\text { hukum) } \\
\text { status lahan } \\
\text { yang } \\
\text { ada.sebagai } \\
\text { acuan } \\
\text { pengembanga } \\
\text { n biaya } \\
\text { perencanaan } \\
\text { kawasan } \\
\text { bumi } \\
\text { perkemahan } \\
\text { sibolangit. }\end{array}$ \\
\hline $\begin{array}{l}\text { Ancaman/ } \\
\text { Threats }\end{array}$ & Strategi S T & Strategi W T \\
\hline $\begin{array}{l}\text { Fasilitas } \\
\text { dan } \\
\text { aksesibilit } \\
\text { as yang } \\
\text { kurang } \\
\text { baik } \\
\text { membuat } \\
\text { kawasan } \\
\text { pramuka } \\
\text { kurang } \\
\text { berkarakte } \\
\text { r. Hal ini } \\
\text { membuat } \\
\text { kawasan } \\
\text { pramuka } \\
\text { kurang } \\
\text { terawatt } \\
\text { padahal } \\
\text { kawasan } \\
\text { bersifat } \\
\text { perkemah } \\
\text { an bersifat } \\
\text { Lokal, } \\
\text { Regional, } \\
\text { dan } \\
\text { Nasional }\end{array}$ & 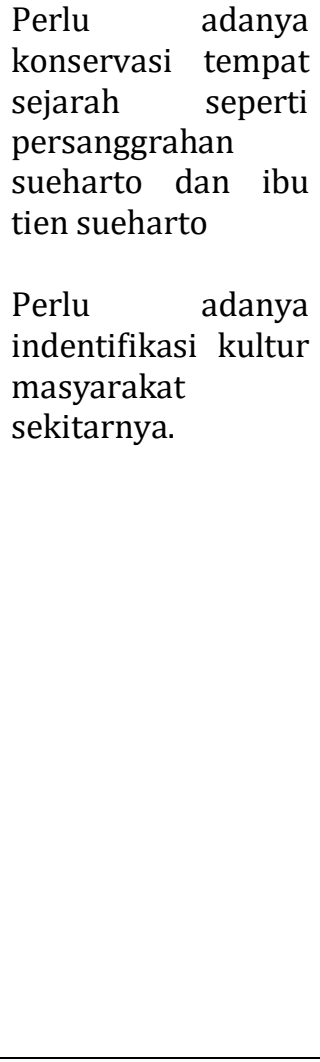 & $\begin{array}{l}\text { Perlu adanya } \\
\text { suatu } \\
\text { pemahaman } \\
\text { (sosialisasi) } \\
\text { yang lebih } \\
\text { mendasar } \\
\text { kepada dan } \\
\text { dari } \\
\text { masyarakat } \\
\text { agar } \\
\text { menyadari } \\
\text { pentingnya } \\
\text { pengembanga } \\
\text { n biaya } \\
\text { perencanaan } \\
\text { kawasan } \\
\text { bumi } \\
\text { perkemahan } \\
\text { pramuka } \\
\text { sibolangit }\end{array}$ \\
\hline
\end{tabular}

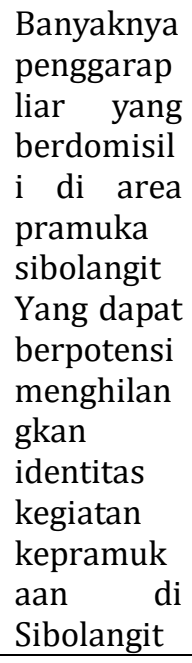

Untuk mendukung Kekuatan, Peluang dan meminimalkan Kelemahan, Ancaman, maka dibutuhkan strategi-strategi yang efektif dan efisien, sehingga tujuan dan sasaran pembangunan kawasan dapat tercapai. Strategi-strategi yang diambil berupa :

Strategi Fisik :

a) Pengembangan kualitas dan penataan jalan utama terkait dengan aksesbilitas

b) Pemanfaatan secara optimal topografi tanah yang datar dan curam terkait dengan pengembangan.

c) Mengembangkan kawasan jalan utama dan tata bangunan sebagai pemicu perkembangan kawasan perkemahan bumi sibolangit.

d) Pengembangan daerah komersil di sepanjang jalan utama sebagai salah satu pemasukan utama kawasan bumi perkemahan sibolangit

e) Penataan untuk fungsi-fungsi elemen kawasan dan pemanfaatan eksisting bangunan-bangunan yang berdiri di kawasan bumi perkemahan sibolangit.

Strategi Non-Fisik :

a) Perlu adanya pengaturan yang jelas tentang tata guna lahan 
b) Peningkatan kesadaran warga melalui ormas-ormas terkait dengan pentingnya peran pengembangan kawasan bumi perkemahan pramuka sibolangit.

c) Perlu adanya sistem pengawasan keamanan di kawasan pramuka sibolangit

d) Perlu adanya penyuluhan mengenai pentingnya kelestarian hutan lindung dalam kawasan pramuka sibolangit

e) Perlu diadakan pengaturan tentang tata letak bangunan.

f) Perlu adanya sosialisasi mengenai pentingnya pengembangan kawasan pramuka untuk industri parawisata

g) Perlu penyuluhan tentang partisipasi masyarakat dalam pengembangan

h) Legalisasi peruntukan lahan dan tata bangunan perlu diatur kembali.

i) Peningkatan kesadaran warga tentang pengembangan kawasan pramuka sibolangit untuk memperbaiki kualitas hidup.

j) Peningkatan sarana dan prasarana untuk mendukung perkemahan pramuka sibolangit.

\section{SIMPULAN}

Kawasan Sibolangit merupakan salah satu kawasan yang berfungsi sebagai suaka alam dan margasatwa untuk melindungi keanekaragaman hayati, ekosistem dan keunikan alam. Fungsi dari Bumi perkemahan Sibolangit dikenal sebagai tempat kalangan Pramuka, serta kelompok masyarakat lainnya, untuk melakukan setiap kegiatan outdoor, baik untuk camping, rekreasi, tracking, serta kawasan wisata pada beberapa area yang seharusnya tertutup untuk kegiatan kemah, justru dibuka secara bebas bagi khalayak umum. Namun jumlah kunjungan wisatawan yang masih rendah untuk meningkatkan kontribusi pariwisata terhadap pendapatan masyarakat dan pemerintah daerah.
Banyaknya jumlah obyek wisata yang belum mendapat perhatian dan pengelolaan secara baik, serta pengelolaan dan pengembangan obyek wisata yang belum memperhatikan potensi dan strategi pengembangan. Dengan melakukan analisis diharapkan mendapatkan stratei dalam pengembangan kawasan wisata baik strategi fisik dan strategi non fisik. Diharapkan dengan strategi ini, menjadi strategi pengembangan baik sarana dan prasarana sehingga meningkatkan fungsi wisata terhadap kawasan untuk peningkatan kawasan dan masyarakat setempat. Penelitian ini bisa dapat menjadi dasar dari penelitian maupun perancangan pada kawasan Sibolangit.

\section{DAFTAR PUSTAKA}

Andajani, E., Widjaja, F. N., \& Prihatiningrum, A. E. (2017). Pengembangan Potensi Desa Wisata melalui Analisa SWOT Di Kecamatan Kalitidu Bojonegoro. Senaspro2, 909-915.

Https://diskominfo.sumutprov.go.id/. (2020). PEMPROV SUMUT SEGERA KEMBALIKAN FUNGSI BUMI PERKEMAHAN SIBOLANGIT.

https://diskominfo.sumutprov.go.id/artikel3260-pemprov-sumut-segera-kembalikanfungsi-bumi-perkemahan-sibolangit.html

Kementerian Pekerjaan Umum dan Perumahan Rakyat, \& Konstruksi, B. P. S. D. M. P. P. dan P. S. D. A. dan. (2017). Modul 1 Pemahaman Umum Studi Kelayakan Proyek Infrastuktur. 53.

Rambe, Y. S. (2020). Identifikasi dan Konsep Pengembangan Kawasan Ruang Terbuka Hijau (RTH) Kota Padangsidimpuan. Arsitektura, 18(2), 337. https://doi.org/10.20961/arst.v18i2.44377

Ramdan, R. M., \& Ihkwana, A. (2016). Analisa Kelayakan Pengembangan Wisata di Desa. Cimareme Kecamatan Banyuresmi Garut. Jurnal STT Garut, 14(1), 101-110.

Rangkuti, F. (2017). Teknik membedah kasus bisnis Analisis SWOT (cara perhitungan bobot, rating dan OCAI). PT. Gramedia Pustaka Utama. Jakarta.

Serdang, P. K. D. (2019). RTRW Kabupaten Deli Serdang 2019-2039.

Sugiyono. (2017). Metode Penelitian Kuantitatif, Kualitatif, dan R\&D. Bandung: Alfabeta, CV. 
Rambe Y.S, Analisis Kelayakan Fungsi Wisata sebagai Strategis Pengembangan Bumi Perkemahan Sibolangit

Sukmana, B. D., \& Suryawan, I. B. (2016). Daya Dukung Lingkungan Fisik Terhadap Kelayakan Daya Tarik Wisata Taman Tirta Gangga Desa Ababi Kabupaten Karangasem. Jurnal Destinasi Pariwisata, 4(1), 7. https://doi.org/10.24843/jdepar.2016.v04.i01 .p02

Sukmaratri, M. (2018). Kajian Objek Wisata Sejarah Berdasarkan Kelayakan Lanskap Sejarah Di Kota Palembang. Jurnal Planologi, 15(2), 164. https://doi.org/10.30659/jpsa.v15i2.3071

Tarigan, N. P., Purwanti, F., \& Hendrarto, B. (2018). Kelayakan Wisata Alam Di Maroon Mangrove Edu Park Semarang. Management of Aquatic Resources Journal (MAQUARES), 6(3), 274-282.

https://doi.org/10.14710/marj.v6i3.20586 